\title{
Creditor Rights, Technology Adoption, and Productivity: Plant-Level Evidence
}

by

\author{
Nuri Ersahin \\ University of Illinois at \\ Urbana Champaign
}

\section{CES 17-36 April, 2017}

The research program of the Center for Economic Studies (CES) produces a wide range of economic analyses to improve the statistical programs of the U.S. Census Bureau. Many of these analyses take the form of CES research papers. The papers have not undergone the review accorded Census Bureau publications and no endorsement should be inferred. Any opinions and conclusions expressed herein are those of the author(s) and do not necessarily represent the views of the U.S. Census Bureau. All results have been reviewed to ensure that no confidential information is disclosed. Republication in whole or part must be cleared with the authors.

To obtain information about the series, see www.census.gov/ces or contact J. David Brown, Editor, Discussion Papers, U.S. Census Bureau, Center for Economic Studies 5K034A, 4600 Silver Hill Road, Washington, DC 20233, CES.Working.Papers@census.gov. To subscribe to the series, please click here. 


\begin{abstract}
I analyze the impact of strengthening of creditor rights on productivity using plant-level data from the U.S. Census Bureau. Following the adoption of anti-recharacterization laws that improve the ability of lenders to access the collateral of the firm, total factor productivity of treated plants increases by 2.6 percent. This effect is mainly observed among plants belonging to financially constrained firms. Furthermore, treated plants invest in capital of younger vintage and newer technology, and become more capital-intensive. My results suggest that strengthening of creditor rights leads to a relaxation in borrowing constraints, and helps firms adopt a more efficient production technology.
\end{abstract}

Keyword: Creditor Rights; Productivity; Anti-Recharacterization Laws; Bankruptcy

JEL Classification: D24, G32, G33, K22

\footnotetext{
* I would like to thank my dissertation committee members, Heitor Almeida, Rustom Irani, Scott Weisbenner, and Yuhai Xuan for the valuable suggestions and support. I thank Steven Harris, Jiekun Huang, Timothy Johnson, Charles Kahn, Mathias Kronlund, Simone Lenzu, Neil Pearson, Joshua Pollet, Adrian Walters, and Yufeng Wu for helpful comments. I am grateful to Frank Limehouse for all his help at the Chicago Census Research Data Center. The research in this article was conducted while I was Special Sworn Status researcher of the U.S. Census Bureau at the Chicago Census Research Data Center. Any opinions and conclusions expressed herein are mine and do not necessarily represent the views of the U.S. Census Bureau. All results have been reviewed to ensure that no confidential information is disclosed. Ersahin email: ersahin2@illinois.edu.
} 


\section{Introduction}

There is an influential body of research arguing that financial and legal institutions affect economic growth (King and Levine, 1993; La Porta et al., 1997; Rajan and Zingales, 1998); however, much less is known about the specific channel. The effect of these institutions on financing constraints, technology adoption, and productivity is a candidate explanation (Hicks, 1969) 1 The purpose of this study is to investigate the importance of the rights of secured creditors in bankruptcy for the productivity of businesses.

On the theoretical front, the effect of creditor rights on productivity is far from obvious. On the one hand, strengthening of creditor rights, such as an increased ability to recover collateral in the event of financial distress, might encourage lending by creditors. The relaxation in borrowing constraints might lead to higher technology adoption by firms, which will help them operate more efficiently (Midrigan and $\mathrm{Xu}, 2014)$. On the other hand, strengthening of creditor rights may increase the costs of financial distress for firms and managers, leading them to avoid risky but innovative projects, which can be detrimental to the productive efficiency (Acharya et al., 2011; Acharya and Subramanian, 2009).

The endogeneity of creditor rights constitutes the greatest obstacle hindering any attempt to study the effect of creditor rights on productivity. There might be a variety of unobservable factors affecting both creditor rights in a country or a state and the performance of firms. To overcome this obstacle, I use enactment of anti-recharacterization statutes as a source of exogenous variation in creditor rights (e.g., Li et al., 2016). These laws mainly affected the securitization industry and firms using a special purpose vehicle (SPV) to conduct secured borrowing. Collateral is transferred to an SPV for the purpose of protecting it from automatic stay in case of the bankruptcy of the debtor. However, before these laws, bankruptcy judges

\footnotetext{
${ }^{1}$ Productivity shocks have been modeled as an important driver of economic fluctuations in a variety of macroeconomic models beginning with Kydland and Prescott (1982). Moreover, Klenow and RodriguezClare (1997), and Hall and Jones (1999) argue that differences in productivity are critical to understanding output differences between countries.
} 
had the discretion to make the collateral in the SPV subject to automatic stay. These laws significantly increased the rights of secured creditors in bankruptcy by denying judges this discretion and allowing secured creditors to seize the collateral in the SPV ${ }^{2}$

I adapt the empirical methodology of Bertrand and Mullainathan (2003) to study the effect of anti-recharacterization laws based on plant-level data from the U.S. Census. The granularity of the Census data coupled with the fact that anti-recharacterization laws were adapted at the state of incorporation level helps me conduct two types of analysis. First, the Census data provide the exact geographic location and industry of each plant, which allows me to compare the change in productivity of two plants in the same year, industry, and location. To illustrate, I am able to compare the productivity change of two plants in Iowa, one of which belongs to a firm incorporated in Texas (a treated state), and the other which belongs to a firm incorporated in California (a control state). This plant-level analysis allows me to observe the productive efficiency of a plant far from the state of headquarter or state of incorporation, and separately identify the effect of stronger creditor rights from local economic shocks contemporaneous with the laws. Second, the longitudinal nature of the plant-level data helps me observe the productivity of a plant for several consecutive years, which is crucial in the context of my study given that effects on productivity may take time to materialize.

Following the adoption of anti-recharacterization laws, total factor productivity of plants belonging to treated firms increases significantly by 2.6 percent. In addition to total factor productivity, capital and labor productivities increase. The fact that these laws are passed by states and they are not driven by firm-specific conditions alleviates the concern of endogeneity. However, the possibility that these laws are passed in response to changing eco-

${ }^{2}$ There is a substantial number of firms using SPVs. Using 6,473 public firms between 1997 and 2004, Feng et al. (2009) find that on average 42 percent of firms use at least one SPV. In 2004, 59 percent of firms report at least one SPV, which shows that their use is quite prevalent. Furthermore, Korgaonkar and Nini (2010) state that firms in manufacturing and production of consumer durables use special purpose vehicles intensively. 
nomic conditions needs to be addressed. I conduct two tests to address this concern. First, I conduct a dynamic analysis and show insignificant effects before the passage of these laws. Second, I conduct a placebo test, falsely assuming that neighboring states are treated. If my estimates are simply picking up economic shocks near the geography of Texas, Louisiana, and Alabama, then I should be able to see significant effects for neighboring states as well. Estimates from this falsification test are statistically indistinguishable from zero, which shows that the effect on productivity is coming only from states that enacted these laws.

In the second part of my empirical analysis, I try to uncover the channel through which strengthening of creditor rights translates into increasing productive efficiency. First, I demonstrate that the increase in productivity is related to financial constraints: plants belonging to financially constrained firms show substantial increase in productivity, whereas I do not see any significant change in the productivity of plants belonging to unconstrained firms. Second, the granularity of the Census Data allows me to document two important changes in the composition of investment that are motivated by the literature on financial constraints and investment. First, treated plants adopt more advanced technology by investing in capital of younger vintage and newer technology: new machinery and computer investments increase significantly at treated plants. Eisfeldt and Rampini (2007) show that investing in used capital rather than new capital is very common among credit constrained firms $:^{3}$ In line with their finding, I document that the fraction of capital expenditures on new machinery increases significantly at treated plants following the enactment of antirecharacterization laws. The second compositional change relates to the ratio of capital to labor. Garmaise (2008) argues that constrained firms are much more labor-intensive in their production process. Therefore, a relaxation of borrowing constraints should be accompanied with a shift to a more capital-intensive production. I examine how new machinery scaled by

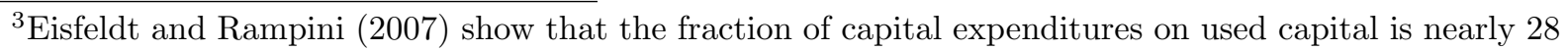
percent in the smallest size decile.
} 
labor changes at treated plants and find that new machinery expenditures per unit of labor increase significantly at treated plants, which shows that the production at treated plants is becoming more capital-intensive.

My findings are related to at least two strands of literature. First, I contribute to the literature on creditor rights and their effects on firms. Strengthening of creditor rights can result in inefficient liquidation of firms by increasing the cost of continuing during financial distress Aghion and Bolton, 1992; Hart et al., 1997). This liquidation bias can lead firms to pursue more conservative financing and investment policies ex-ante. Vig $(\overline{2013})$ analyzes the effects of a securitization reform in India on the debt structure of firms. He shows that following a 2002 law that strengthened the rights of secured creditors, firms use less secured debt and hoard more cash, which are indicative of a more conservative financing policy. Acharya and Subramanian (2009), Acharya et al. (2011), and Seifert and Gonenc (2012) present evidence consistent with this view, showing that stronger creditor rights are associated with less innovation, as well as more conservative investment policies. A more recent set of studies show effects contrary to the liquidation bias. Li et al. (2016) show that firms increase leverage significantly following the adoption of anti-recharacterization laws. Using the same laws as well additional court decisions, Mann (2015) documents that firms increase their debt, as well as their innovation output. Using a bankruptcy reform increasing the rights of secured creditors in Brazil, Ponticelli and Alencar (2016) argue that efficient judicial courts increase firm investment and growth. Rather than focusing on financing and investment behaviors of firms, I examine the productivity implications of strengthening of creditor rights.

Second, my study contributes to the literature analyzing the effects of finance on productivity and performance. Butler and Cornaggia (2011) analyze the effects of ethanol-induced change in demand on the productivity of farmers. They find that farmer productivity increases significantly more in areas with high levels of bank deposits. Gatti and Love (2008) 
and Levine and Warusawitharana (2016) show that increased access to finance is associated with TFP growth in a sample of Bulgarian and European firms, respectively. A recent study by Cerqueiro et al. (2016) investigates the effects of a legal reform in Sweden that reduces the collateral value. They show that productive efficiency of treated firms does not change. The closest study to my study is Krishnan et al. (2014). By using Census Data, they show that TFP increases following interstate banking deregulations among the smallest firms in the economy. I complement their study in the following four ways. First, the natural experiment I am using provides a different source of increased access to finance for treated firms. Interstate banking deregulations used by Krishnan et al. (2014) result in increased access to finance through increased bank competition, whereas anti-recharacterization laws allow increased access to finance through shifting the balance of power towards a broader set of creditors. Second, I exploit the granularity of the Census Data to compare two plants in the same state, industry, and year, but with different state of incorporation, which provides a very clean identification. Third, I show that the move to a newer and more capital-intensive production technology following a relaxation of borrowing constraints is the channel behind increasing productivity. Finally, I show that public firms' productivity also is affected by increased access to finance.

The remainder of this paper is organized as follows. Section 2 describes anti-recharacterization laws in great detail. Section 3 presents the data and empirical methodology. Section 4 provides firm and plant-level empirical results. Section 5 concludes.

\section{Anti-Recharacterization Laws}

I begin by describing anti-recharacterization laws that affected the securitization industry and firms using a special purpose vehicle (SPV) to conduct secured borrowing. Collateral is transferred to an SPV, which is a financial intermediary designed to be bankruptcy remote, 
then sold to investors as securities. The main reason for transferring assets to a different entity is to characterize them as sales, thereby protecting them from automatic stay in case of bankruptcy of the issuing firm. The bankruptcy remoteness of an SPV is intended to ensure investors that obligations will be fulfilled even if the SPV originating firm goes bankrupt. However, the bankruptcy-remoteness of an SPV should not be taken for granted. Sometimes bankruptcy courts can recharacterize the asset transfer as a secured loan rather than a true sale, making the SPV assets subject to automatic stay. Such discretion of bankruptcy courts is generally justified by stating that the SPV will play an important role in the reorganization of the bankrupt firm. The enactment of anti-recharacterization laws discards the possibility of recharacterization by bankruptcy courts.

These laws are enacted in seven states: Texas and Louisiana in 1997, Alabama in 2001, Delaware in 2002, South Dakota in 2003, Virginia in 2004, and Nevada in 2005. Kettering (2011) states that these seven states can be divided to two in terms of the coverage of their anti-recharacterization laws. In Texas and Louisiana, Section 9.109 of Uniform Commercial Code (U.C.C.) discards the possibility of recharacterization for all sales of receivables, whereas in the other states, the possibility of recharacterization is prevented only for sales under a securitization transaction 4

A deeper look at these anti-recharacterization laws shows that these laws affect a substantial number of transactions. Section 9.109 of Texas and Louisiana Uniform Commercial Code (U.C.C.) explicitly discards the possibility of recharacterization of the sale of the following four items: accounts, chattel paper, payment intangibles, and promissory notes $5^{5}$ The

\footnotetext{
${ }^{4}$ Appendix B states the section of the state statutes that guarantees anti-recharacterization for Texas, Louisiana, and Alabama that constitute my treatment states.

${ }^{5}$ Part of Section 9.109 of Texas and Louisiana Uniform Commercial Code (U.C.C.) that explicitly discards the recharacterization: "The application of this chapter to the sale of accounts, chattel paper, payment intangibles, or promissory notes is not to recharacterize that sale as a transaction to secure indebtedness but to protect purchasers of those assets by providing a notice filing system. For all purposes, in the absence of fraud or intentional misrepresentation, the parties' characterization of a transaction as a sale of such assets shall be conclusive that the transaction is a sale and is not a secured transaction and that title, legal and equitable, has passed to the party characterized as the purchaser of those assets regardless of whether the
} 
most important item for the purposes of my study is "Accounts", defined in Section 9.102 of Uniform Commercial Code (U.C.C.). "Account" means a right to payment of a monetary obligation, whether or not earned by performance, for a variety of items including (i) property that has been or is to be sold, leased, licensed, assigned, or otherwise disposed of, (ii) services rendered or to be rendered, (iii) a policy of insurance (iv) licensing of intellectual property, and (v) credit cards. As can be seen, this definition of accounts goes beyond the traditional definition of accounts consisting mainly of trade receivables.

In Alabama, which constitutes my third treatment state, and the remaining four states, anti-recharacterization is guaranteed by an act that precludes recharacterization of a sale of property of any kind included in a securitization transaction. In Appendix B, as can be seen in Section 35-10A-2 of the Code of Alabama, no property, assets, or rights transferred to a special purpose vehicle (SPV) can be subject to recharacterization. Assets typically transferred to an SPV include trade receivables, residential and commercial loans, equipment leases, licenses, and management contracts.

Taken together, these laws increase the pledgeability of any rights to future payment, receivables, by making them more accessible to creditors. Especially manufacturing firms, which constitute my sample, generate large amount of receivables. Nini and Korgaonkar (2010) state that firms in manufacturing and production of consumer durables are heavy users of special purpose vehicles. For this reason, I expect these anti-recharacterization laws to have a significant effect on manufacturing firms.

The use of securitization is not confined to manufacturing firms. Feng et al. (2009) document that the percentage of firms using at least one SPV increases from 23 percent in 1997 to 59 percent in 2004, which confirms how common they become in the time period my sample covers. Finally, these laws are fairly exogenous to the firms included in my sample. secured party has any recourse against the debtor, whether the debtor is entitled to any surplus, or any other term of the parties' agreement." 
Kettering (2008) describes the enactment of anti-recharacterization laws as a great success of the securitization industry. Janger (2003) constitutes another study arguing for the big role played by the financial industry in the enactment of anti-recharacterization laws. I will return to the endogeneity concern due to lobbying by industrial firms in Section 4.1.1.

\section{$3 \quad$ Data and Empirical Methodology}

I adapt the empirical methodology of Bertrand and Mullainathan (2003) in the sample construction and the plant-level analysis. In this section, I describe each step in detail.

\subsection{Data Sources}

The main data I use in this study is a combination of two datasets from the Census. Both datasets cover only U.S. manufacturing plants. The first manufacturing plant dataset is the Census of Manufacturers (CMF). The CMF is conducted every five years and consists of all manufacturing plants in U.S. with at least one paid employee. The second manufacturing dataset is the Annual Survey of Manufacturers (ASM). ASM is conducted in years where CMF is not conducted and includes a subset of plants surveyed in CMF. Establishments with 250 employees and above are always included in this sample, whereas plants with smaller number of employees are chosen randomly with a probability positively correlated with their number of employees. Both of these datasets include detailed information on industry, corporate affiliation, total shipments, employment, capital expenditures, and material inputs of each plant. Reporting for both of these surveys is mandatory and misreporting is penalized, which alleviates misreporting and response rate concerns. The level of granularity of these manufacturing datasets plays a critical role in my analysis. First, it allows me to construct various measures of productivity for each manufacturing plant, and thereby analyze how the

productivity of a plant and the creditor rights are related. Second, it helps me study how 
the vintage of productive assets as well as the capital-labor ratio are affected by providing granular and reliable machinery, computer, and employment numbers.

In addition to these two manufacturing datasets, I use another dataset from the Census, the Longitudinal Business Database (LBD). LBD keeps yearly track of all business establishments in U.S. with at least one paid employee. It provides information on the number of employees, payroll, geographical location, industry, and corporate affiliation for each establishment. For the purpose of this study, I use LBD to get information about the age of the plant as well as the number of plants owned by the firm the plant belongs to.

Finally, I use firm-level data from Compustat. I confine my analysis to public firms because I can observe the state of incorporation only for public firms. I use the Compustat bridge maintained by the Census to match firms in Compustat to plants. However, this bridge ends in 2005. I extend the bridge to 2009 by making use of various employer characteristics including name, address, and identification number (EIN). My sample covers the period from 1992 to 2009.

\subsection{Variable Construction and Summary Statistics}

I follow Li et al. (2016) in the construction of the anti-recharacterization treatment variable, which constitutes the main independent variable in this study. The anti-recharacterization laws were enacted in seven states: Texas and Louisiana in 1997, Alabama in 2001, Delaware in 2002, South Dakota in 2003, Virginia in 2004, and Nevada in 2005. However, as argued in Li et al. (2016), the 2003 federal court ruling on Reaves Brokerage Company, Inc. vs. Sunbelt Fruit \& Vegetable Company, Inc. case significantly harmed the influence of these laws by creating a precedent that anti-recharacterization laws could be overruled by federal courts. For this reason, I only include Texas, Louisiana, and Alabama in the set of treated states.

Following Li et al. (2016), I consider firms incorporated in Texas, Louisiana, and Alabama 
between 1997 and 2003 as treated firms. I also include firms whose headquarter are in those states between 1997 and 2001 in the set of treated firms. The question of which state law will govern recharacterization is quite complicated ${ }^{6}$ Article 9 of Uniform Commercial Code (U.C.C.) specifies the rules governing secured transactions, including securitization. A revised version of Article 9, effective as of July, 2001, states that the law governing a secured party's interest in receivables is the law of the location of the debtor, which is defined to be the state in which the entity is registered. For corporations, this definition of location of debtor means the state of incorporation. However, the old version of Article 9, effective before June, 2001, deemed the debtor's location to be the location of its chief executive office, which is the headquarter. The official comment to this older version of Article 9 explicitly states that the chief executive office does not mean the place of incorporation but is the place from which the debtor manages the main part of his business operations. Therefore, before 2001, the state of headquarter needs to be taken into account.7

The main dependent variable I use in this study is the natural logarithm of total factor productivity (TFP), which I am constructing at the plant-level following the methodology in Foster et al. (2014).

$$
\mathrm{TFP}_{i t}=\ln \mathrm{Q}_{i t}-\alpha_{k t} \ln \mathrm{K}_{i t}-\alpha_{l t} \ln \mathrm{L}_{i t}-\alpha_{m t} \ln \mathrm{M}_{i t}
$$

Where $i$ and $t$ index plant and year, respectively. The variables TFP, Q, K, L, M, and $\alpha$ represent total factor productivity, real output, capital stock, labor input, cost of materials and parts, and factor elasticities, respectively. $\left.\right|^{8}$ Output is constructed by summing the total value of shipments and change in inventories for finished goods and work-in-process. Because the Census does not collect establishment-level prices, I use an industry-level measure from

\footnotetext{
${ }^{6}$ See Kettering (2011) for an extensive analysis of the choice of law governing recharacterization.

${ }^{7}$ See Appendix C for the choice of law rules specified in both old and new versions of Article 9.

${ }^{8}$ See Foster et al. (2014) for a more detailed explanation of how each variable is constructed.
} 
the NBER-CES Manufacturing Industry Database to deflate output. The use of an industrylevel price gets me closer to the real output.

A perpetual inventory method is used to construct capital stock that consists of structure and equipment belonging to the plant. The first year a plant is seen in the CMF/ASM is taken as a starting point to construct capital stock series. Capital expenditures using investment price deflators from the BLS at the 2-digit SIC or 3-digit NAICS level are added to the capital stock each year. An industry-level depreciation rate from the Bureau of Economic Analysis is used. Capital stock series are constructed for structure and equipment separately. They are then added to represent the total capital stock owned by the plant. Following Brav et al. (2015), I use "production-worker equivalent hours" as my measure of labor input. This measure is constructed by multiplying number of hours worked by production-workers with the ratio of total wages and salaries to total wages and salaries paid to production workers. Materials costs include both non-energy and energy related costs. Non-energy materials costs include costs of materials and parts as well as cost of resales and contract work. Energy costs include electricity and fuel costs. Both types of costs are deflated by their corresponding industry deflator. Finally, following Syverson (2011) and Foster et al. (2014), I use industrylevel factor cost shares for factor elasticities. I get the industry-level cost shares for capital, labor, materials, and energy expenditures from the NBER Productivity Database.

In addition to total factor productivity, I analyze the effects of strengthening of creditor rights on factor productivities, including labor and capital productivities. I use the measure of labor productivity used in Brav et al. (2015) and Silva (2013): natural logarithm of valueadded per labor hour, which is the total value of shipments minus material and energy costs divided by total labor hours. As to capital productivity, I follow Giroud and Mueller (2015), and use Return on Capital (ROC), which is calculated as the total value of shipments minus labor, material, and energy costs scaled by capital stock. All inputs are measured in 1997 dollars. 
In the second part of the empirical analysis where I try to uncover the determinants of increased productivity, I use two variables: new machinery investment and computer investment. New machinery investment is constructed by scaling new machinery expenditures by lagged capital stock. Following Brav et al. (2015), I use variable for capital expenditures for computers from the CMF and ASM databases and scale it by lagged capital stock to represent investment in information technology (IT). Specifically, capital expenditures for computers stand for computer hardware, software, and networks expenditures. I have this variable starting with 2000.

In Table X, I examine how new machinery expenditures scaled by labor change following the enactment of anti-recharacterization laws. To ensure robustness of my findings, I use four different variables to represent labor. First, I use total payroll to represent aggregate amount of wages and salaries. Second, I use production payroll to represent amount of wages and salaries paid to production workers. Third, I use employees to represent number of employees. Finally, I use total hours to represent number of hours worked at the plant. I winsorize all variables at 1 percent to ensure that results are robust to outliers.

Table I presents summary statistics for the aggregate sample as well as the subsample of plant-year observations treated by anti-recharacterization laws.$^{9}$ The final sample contains 220,000 plant-year observations covering the period between 1992 and 2009 ${ }^{10}$ As seen, the subsample of treated plants accounts for a relatively small fraction of the total plant-year observations. However, the treated subsample nearing ten thousand plant-year observations is sufficient, given that the treatment effect requires only that the treated subsample be sufficiently large in absolute terms, as argued in Giroud (2013). Untreated plants are older and bigger, which constitutes one of the main reasons why I include age of plants and their total value of shipments to control for differences between treated and untreated plants.

\footnotetext{
${ }^{9}$ Following the disclosure requirements of the Census, quantile values are not reported; I round off number of observations in each table.

${ }^{10}$ Changing the end year from 2009 to 2007 or 2005 does not change my results.
} 


\subsection{Identification and Empirical Model}

I follow closely Bertrand and Mullainathan (2003) in my empirical strategy. The only difference is that, in my setting, not only the state of incorporation but also the state of headquarter plays a role. In the first part of my empirical analysis, I estimate the following equation:

$$
\mathrm{y}_{i f h k l s t}=\alpha_{l s t}+\alpha_{i}+\alpha_{h}+\alpha_{k}+\gamma \mathrm{X}_{i f h k l s t}+\delta \mathrm{ARL}_{h k t}+\epsilon_{i f h k l s t},
$$

where $i, f, h, k, l, s$ and $t$ index plant, firm, state of headquarter, state of incorporation, state of location, industry, and year, respectively. The unit of observation is a plant-year. The variable y stands for variables related to productivity and investment: total factor productivity (TFP), labor productivity, return on capital, new machinery investment, and computer investment. $\mathrm{ARL}_{h k t}$ is an indicator variable that equals one if the plant belongs to a firm whose state of headquarter or state of incorporation passed an anti-recharacterization law within the past three years (t, t-1, and t-2). Following Bai (2016), I take the last three years into account given that the effect of these laws on productivity may take longer to materialize. $\alpha_{l s t}, \alpha_{i}, \alpha_{h}$, and $\alpha_{k}$ are state of location-industry-year, plant, state of headquarter, and state of incorporation fixed effects, respectively. $\mathrm{X}_{i f h k l s t}$ stands for plant and firm controls: total value of shipments, age of the plant, and number of plants owned by the firm the plant belongs to. Age is defined based on the first year the plant is first seen on LBD records. Industry is defined at the two-digit SIC level. Following Bertrand and Mullainathan (2003), I cluster standard errors at the state of location level.

I control for time-invariant characteristics at the plant-level through plant fixed effects. Following Bertrand and Mullainathan (2003), I use state of incorporation fixed effects to control for time-invariant differences between treated and untreated plants. In addition, I use state of headquarter fixed effects, given that my definition of treatment includes both 
state of incorporation and state of headquarter. The state of location dummies interacted with industry and year dummies, $\alpha_{l s t}$, allow me to fully control for contemporaneous shocks at the state of location and industry level. There are two main reasons why I use state and industry dummies. First, as documented in Foster et al. (2014), total factor productivity shows considerable variation across industries. For this reason, industry differences need to be controlled. Second, the TFP measure I am using is essentially a revenue measure. Demand shocks at different geographies may inflate or deflate my TFP measure in a way totally unrelated to the productive efficiency, which constitutes the main reason why I control for state of location. For these two main reasons, I use state-industry-year fixed effects to fully control for contemporaneous shocks at the state of location. I use fixed effects instead of demeaning the dependent variable at the state-industry-year level because demeaning can lead to inconsistent estimates (Gormley and Matsa, 2013). The coefficient of interest is $\delta$, which measures the effect of anti-recharacterization laws on TFP.

One potential problem is related to the endogeneity of anti-recharacterization laws. If firms in my sample lobbied for these laws, then enactment of these laws might be correlated with unobserved factors affecting firms' productivity. First, Kettering (2008) describes the enactment of anti-recharacterization laws as a great success of the securitization industry. Kettering (2008) argues that these statutes are the product of efforts by the financial industry to totally abolish the possibility of recharacterization. Second, I address this concern with a dynamic analysis explained in great detail in section 4. If these laws are the result of economic factors leading firms to lobby for them, then I should be able to detect their effect before their enactment. My dynamic analysis shows no such effect. 


\section{Empirical Results}

This section documents how anti-recharacterization laws affect firms' productivity as well as their investment decisions. In Section 4.1, I analyze how stronger creditor rights affect total as well as factor productivities. In Section 4.2, I analyze what investments firms are making to increase their productivity.

\subsection{Anti-Recharacterization Laws and Productivity}

I first estimate equation (2) with the natural logarithm of total factor productivity as the dependent variable. Table II presents the results.

Column [1] presents results from estimation of equation (2) with only plant and year fixed effects. The estimated coefficient of interest, which is the one on ARL, is 0.032 , and it is significant at 1 percent confidence level. The positive sign of this estimate is in line with the prediction that strengthening of creditor rights will lead firms to operate more efficiently. To put this estimate in economic terms, I follow Schoar (2002) and Krishnan et al. (2014). Holding inputs constant, a 3.2 percent increase in total factor productivity corresponds to a 3.2 percent increase in revenues. Since the elasticity of profits to total factor productivity is greater than one, increase in revenues will result in a greater increase in profits, the magnitude of which will depend on the profit margin. Assuming a profit margin of 20 percent or 40 percent, a 3.2 percent increase in total factor productivity will lead to to a 16 percent or 8 percent increase in profits, respectively, which is economically significant.

Column [2] adds state of incorporation and state of headquarter fixed effects to control for time-invariant differences between treated and untreated firms. The inclusion of these fixed effects decreases the estimated coefficient to 0.027. However, this coefficient is still significant at 1 percent confidence level, and translates into a 2.7 percentage points increase 
in total factor productivity.

Column [3] adds state of location-industry-year fixed effects to the estimation in column [2] to further tighten the specification. As discussed in Section 3.3, these interacted dummies allow me to control for contemporaneous shocks at the state of location level. The inclusion of these controls makes a small change to the estimated coefficient of interest, which is 0.026 and significant at 1 percent confidence level. The enactment of anti-recharacterization laws is associated with an economically and statistically significant increase in total factor productivity.

In Table III, I look at the effects of anti-recharacterization laws on factor productivities. Columns [1] to [3], and [4] to [6] report results for labor and capital productivity, respectively. For labor productivity, the estimated effect of anti-recharacterization laws shows little variation across specifications, ranging between 0.057 and 0.068. Estimates are both eco-

nomically and statistically significant, which suggests that increase in labor productivity is an important driver of an increase in total factor productivity.

In columns [4] to [6], I follow Giroud and Mueller (2015), and use Return on Capital (ROC), which is calculated as total value of shipments minus labor, material, and energy costs scaled by capital stock to proxy for capital productivity. Estimated coefficients are both economically and statistically significant.

Taken together, these estimates indicate that the passage of anti-recharacterization laws leads to an economically large and statistically robust effect on total factor productivity and capital and labor productivities of treated plants. These estimates suggest a positive impact of strengthening of creditor rights leading firms to operate more efficiently.

\subsubsection{Robustness Checks}

I next conduct several tests to ensure the robustness of the results in Table II. One potential problem is that spurious correlation might be driving the results in Table II. Some 
unobserved covariates or changing economic conditions might be inducing firms to operate more efficiently as well as lobby for the anti-recharacterization laws. While there seems to be no perfect way to address this concern, I estimate a dynamic version of equation (2) to investigate when the effects of these laws materialize. If there is a spurious correlation due to changing economic conditions, it is reasonable to expect a significant effect on productivity before the passage of these laws.

Table IV investigates the dynamic effects of anti-recharacterization laws. In column [1], the estimated coefficient on Before ${ }^{-1}$ is economically small and statistically insignificant. The estimated coefficient on Before ${ }^{0}$, which represents the year anti-recharacterization laws passed, is economically bigger. However, it lacks statistical significance. Finally, the coefficients on After $^{1}$ and After $^{2+}$ are both economically and statistically significant. In line with my expectations, this shows that the effects of these laws on total factor productivity start materializing one year after their passage.

Columns [2] and [3] conduct the same analysis in column [1] for labor productivity and return on capital, respectively. In column [2], there is no significant effect on labor productivity before the passage of the laws: the estimated coefficient on Before ${ }^{-1}$ is economically small and statistically insignificant. The coefficient on Before $^{0}$ is 0.060 and significant at 1 percent confidence level. For the following years, the coefficients get bigger: 0.100 and 0.090 for After ${ }^{1}$ and After $^{2+}$, respectively, and they are significant at 1 percent confidence level.

Column [3] further strengthens the causal interpretation of these laws: The coefficient on Before ${ }^{-1}$ is statistically indistinguishable from zero. Taken together, none of the columns in Table IV shows a significant effect of these laws before they are passed, which allays the concerns that these laws were passed as a result of changing economic conditions.

In Table V, I conduct another test to check the validity of the results in Table II and III. One might worry that there are regional shocks affecting firms headquartered or incorporated in treated and nearby states. Hence, my estimates might simply be picking up these regional 
shocks rather than the effect of anti-recharacterization laws. I address this issue in the following way: following Campello and Larrain (2016), I falsely assume that states bordering Texas, Louisiana, and Alabama passed the anti-recharacterization laws. Columns [1] to [3] report results using total factor productivity, labor productivity, and return on capital, respectively, as dependent variables using falsely assumed treated states. None of the three estimations gives a significant result, which shows that results in Table II and Table III are not artifacts of some regional or political shocks affecting states in the near geography of Texas, Louisiana and Alabama.

\subsection{Channel behind Creditor Rights and Increasing Productivity}

\subsubsection{Financial Constraints and Productivity}

From this point on, I investigate the channel through which strengthening of creditor rights translates into increasing productivity. I start by analyzing whether the effect of strengthening of creditor rights on productivity varies with the extent of financial constraints. Li et al. (2016) show that following anti-recharacterization laws, treated firms increase their leverage, which can be considered as a relaxation of firms' borrowing constraints. If firms can't make productivity-enhancing investments because of financial constraints, then a relaxation of borrowing constraints as a result of improved access to collateral by creditors should have a stronger effect on the productive efficiency of constrained firms.

I focus on three different measures of financial constraints. Following Giroud and Mueller (2015), for all three financing constraint measures I use, I take the median value one year before the treatment across all companies to classify firms as financially constrained or financially unconstrained. My first measure of financing constraints is firm size. I classify firms as financially constrained (unconstrained) if their lagged asset value is below (above) the median. Second, I use the size-age (SA) index first used in Hadlock and Pierce (2010). 
I classify firms as financially constrained (unconstrained) if their SA value, which is a linear combination of their asset value and age, is above (below) the median. Finally, I use the Whited-Wu index first used in Whited and Wu (2006). I classify firms as financially constrained (unconstrained) if their Whited-Wu value is above (below) the median.

Table VI presents the results. Columns [1], [3], and [5] show that plants belonging to financially constrained firms experience a significant increase in total factor productivity following the passage of anti-recharacterization laws. Estimated coefficients are statistically significant at 1 percent confidence level. Columns [2], [4], and [6] indicate that there is no significant change in the total factor productivity of plants belonging to financially unconstrained firms. All estimated coefficients are statistically indistinguishable from zero. Results in this section show that following a relaxation of borrowing constraints, financially constrained firms use the extra financing to operate more efficiently.

\subsubsection{Debt}

In this section, I analyze whether strengthening of creditor rights as a result of antirecharacterization laws leads firms to increase their borrowing. On the theoretical front, the effect of strengthening of creditor rights on the borrowing behavior of firms is not obvious. On the one hand, relaxation of collateral constraints would induce firms to borrow more, as predicted in Hart and Moore (1994). On the other hand, as seen in Vig (2013), an increasing access to collateral by creditors might lead firms to decrease their use of secured debt.

Table VII shows that consistent with Hart and Moore (1994) and Li et al. (2016), treated firms increase their borrowing. In columns [1] and [2], long-term debt scaled by total assets increases significantly. The estimated coefficient of interest is statistically significant at 1 percent confidence level. In columns [3] and [4], leverage defined as sum of long-term

and short-term debt divided by total assets, increases significantly. Finally, In columns [5] and [6], the dependent variable is defined to be the natural logarithm of the sum of long- 
term and short-term debt to ensure that the results in columns [1] to [4] are not driven by the asset values in the denominator. Estimated coefficients show that total debt increases approximately by 14 percent, which is economically significant. These results confirm that anti-recharacterization laws relax the borrowing constraints of treated firms by allowing creditors more access to collateral.

\subsubsection{Investment Composition}

Results so far show that firms borrow more and operate more efficiently following the enactment of anti-recharacterization laws. In this section, I will try to establish the link between increased borrowing and increased productively by looking at investments made at the plant-level.

There is an important literature arguing that relaxation of collateral-based lending constraints will result in higher investment by firms 11 However, not all investment is the same in terms of productivity consequences. Firms might be investing in pet projects, or invest in land or building that may have little effect on the efficiency of the production process. Therefore, the composition of investment plays a critical role for productivity.

One aspect of investment composition relevant for productivity is vintage of capital. Eisfeldt and Rampini (2007) show that investing in used capital rather than new capital is very common among credit-constrained firms. They also show that fraction of used capital expenditures relative to total capital expenditures decreases significantly as one moves towards relatively less constrained firms. If new capital is more productive due to technological progress, then firms can become productive by investing in new capital rather than used capital. This line of reasoning is in line with Midrigan and $\mathrm{Xu}(2014)$, who argue that distortion of technology adoption decisions is an important channel through which financial frictions decrease productivity. According to this argument, following the relaxation in borrowing

${ }^{11}$ (Chaney et al., 2012: Gan, 2007, Peek and Rosengren, 2000) are prominent examples of this literature. 
constraints, firms become more productive by increasing their technology adoption.

A second aspect of investment composition relates to capital-labor ratio. Garmaise (2008) argues that constrained firms are much more labor-intensive in their production process. He also predicts that productivity of constrained firms will decrease over time since they can not shift to a more capital intensive production process.

One of the main reasons why there is relatively limited research about the composition of investment is data limitations. Aggregate items like capital investment expenditures or plant, property, and equipment reported by standard corporate data sources can not inform us about the vintage of the productive assets or the number of machines per labor in a manufacturing plant. Furthermore, difficulty of finding reliable firm or plant-level employment numbers constitutes another obstacle against any attempt to analyze capital-intensity of a firm's production.

The Census provides two important variables for my vintage and technology adoption analysis: new machinery expenditures and capital expenditures for computers. Columns [1] to [3] of Table VIII document how the new machinery investment ${ }^{12}$ of treated firms change following the adoption of anti-recharacterization laws. The dependent variable is new machinery investment, calculated by scaling new machinery expenditures by the lagged capital stock. The CMF and ASM databases provide a very detailed description of machinery-related expenditures by differentiating between new and old machinery expenditures. Results indicate that treated plants increase their new machinery investment. The estimated coefficient

\footnotetext{
${ }^{12}$ Census defines the Machinery Expenditures in the following way: "Machinery expenditures include outlays for the following types of equipment: lathes, punch presses and similar machinery and equipment for use in production, as well as office machines and fixtures, computers, furniture, cafeteria and dressing room furnishings, automobiles and tracks, and other similar equipment. Capital expenditures also include the value of major improvements and repairs to existing machinery and equipment, if the cost is capitalized, whether repairs and improvements were purchased or made by employees of the reporting establishment." Census defines the New Machinery Expenditures in the following way: "New Machinery Expenditures consist of capital expenditures during the year for new production machinery and equipment and other new machinery and equipment, including replacements as well as additions to capacity. New equipment manufactured by the plant for use in its own production should be included in this category."
} 
of interest in column [3] is 0.008, and it is significant at 1 percent confidence level. In terms of economic magnitudes, this estimate corresponds to a 7.5 percent increase relative to the sample mean, which is significant.

Capital expenditures for computers constitutes the second variable for the analysis in Table VIII. There is an important literature on the relationship between information technology (IT), computers, and output ${ }^{13}$ Two recent studies in finance literature examine the impact of IT-related investments. First, Brav et al. (2015) show that IT-related investments by hedge funds contribute to the productivity of target firms. Second, Agrawal and Tambe (2016) argue that many employees in target firms benefit from IT-related private equity investments by acquiring new skills. They show that workers treated with a private equity investment earn on average higher wages. Therefore, IT-related investment can be a channel through which strengthening of creditor rights translate into increasing productive efficiency. Columns [4] to [6] of Table VIII document how computer investment changes following the passage of anti-recharacterization laws. The dependent variable is computer investment, defined as capital expenditures for computers scaled by lagged capital stock. I observe that treated plants increase their computer investment. The estimated coefficients are statistically significant at 1 percent or 5 percent confidence level.

A potential problem about results in columns [1] to [6] is that the increase of new machinery and computer investments does not necessarily mean that the productive capital is becoming newer. Used capital expenditures might be increasing as well. To check this, in columns [7] to [9], in line with Eisfeldt and Rampini (2007), I analyze how fraction of new machinery expenditures relative to total capital expenditures changes. I find that fraction of new machinery expenditures relative to total capital expenditures increases significantly

\footnotetext{
${ }^{13}$ By using survey data from 584 establishments and 21 industries, Kelley (1994) shows that computercontrolled machinery is key to efficiency in manufacturing process. Greenman and Mairesse (1996) examine French manufacturing and services industries and argue that use of computer impacts productivity positively. Finally, Black and Lynch (2001), using a nationally representative sample of businesses, show that plant productivity is positively correlated with greater computer usage by non-managerial employees.
} 
at treated plants. Estimated coefficients of interest are statistically significant at 1 percent confidence level in all columns. The estimated coefficient in column [3] is 0.027, and is economically significant given that it constitutes about 12.2 percent of its standard deviation (0.221) among the full sample of plants. Therefore, I make sure that the treated plants are moving towards a younger vintage and newer technology.

The second compositional aspect I analyze relates to the capital intensity of the production. CMF and ASM datasets provide two advantages regarding the labor component of my analysis. First, both datasets are of the highest quality and reliability given that misreporting is penalized. Second, these two datasets provide a variety of labor-related variables including number of employees, total hours worked, total payroll and production payroll, which will allow me to make sure that any result I get about capital-labor ratio is not an artifact of the labor measure I am using.

Results in Table VIII do not necessarily indicate that the production is becoming more capital-intensive. In a plant where number of employees grows faster than machinery, we might wrongfully interpret increases in machinery investment as making the plant more machinery-intensive. Therefore, in Table IX, I analyze new machinery investment in conjunction with labor. The dependent variable is new machinery expenditures scaled by labor. In each column, I use a different variable to represent labor: total payroll, production payroll, employees, and total hours. In column [1], I use total payroll, which represents total amount of wages and salaries. In column [2], I use production payroll, which represents total amount of wages and salaries paid to production workers. In column [3], I use employees, which represents number of employees. Finally in column [4], I use total hours to represent total number of hours worked. Results in all columns indicate that new machinery expenditures per labor increase significantly at treated plants following the adoption of anti-recharacterization laws. Therefore, in line with Garmaise (2008), I show that increasing capital-intensity is associated with relaxation of borrowing constraints and increasing productivity. 
In Table X, I investigate where the increase in productivity reported in Table II is coming from. If financial constraints cause firms not to take up productive projects, a relaxation of these constraints should make the greatest impact on parts of the firm that remained unproductive because of these constraints. This makes more sense in an environment where firms operate in multiple industries and have limited budgets, which makes them unable to make productivity-enhancing investments in all segments they operate. Therefore, I expect that unproductive plants should experience the greatest change in productivity as well as change in productivity-enhancing investments reported in Table VIII and IX. Table X uses total factor productivity one year before the treatment to rank plants. I adopt a within-firm productivity ranking of plants. Columns [1] and [2] use the same dependent variable I used in column [1] of Table X: new machinery expenditures over total payroll, whereas columns [3] and [4] use total factor productivity as the dependent variable. After ranking the plants based on their productivity, I look at how their new machinery expenditures over total payroll and TFP change during the following three years. First, I see that initially unproductive plants experience both an economically and statistically significant increase in productivity. In column [4], the estimated coefficient on ARL $\times$ Unproductive is 0.052 , which translates into a productivity increase of 5.2 percentage points, and is statistically significant at 1 percent confidence level. Productive plants before the treatment do not appear to become more productive, given that the estimated coefficient on ARL $\times$ Productive is statistically indistinguishable from zero. Second, columns [1] and [2] show that initially unproductive plants that happen to experience a substantial increase in productivity are the ones that happen to benefit from an increase in new machinery expenditures per unit of labor. The estimated coefficient on ARL $\times$ Unproductive is statistically different from zero at 1 percent confidence level. Therefore, a within-firm productivity ranking of plants helps me nail down the one-to-one relationship between the increasing productivity and capital intensity reported in the first and second part of my empirical analysis, respectively. 
Taken together, results in Table VI to Table $\mathrm{X}$ show that following the enactment antirecharacterization laws, treated manufacturing firms borrow more and make two compositional changes in their investments: first, they increase the share of total capital expenditures on new capital by increasing new machinery and computer investments. Second, they increase the capital and machine-intensity of their plants. These changes happen to primarily benefit the productivity of initially unproductive plants. This also suggests that the underlying reason why these plants were unproductive in the first place is that productivityenhancing investments were not being done because of financial constraints.

\section{Conclusion}

Using plant-level data from the Census, I first show that total factor productivity of plants belonging to treated firms increases significantly by 2.6 percent following the adoption of antirecharacterization laws in Texas, Louisiana, and Alabama. The granularity of my data helps me compare two plants in the same state, industry, and year. My baseline results survive various robustness checks, including a dynamic analysis of the effects of laws and a placebo test where treated states are falsely assumed to be neighboring states.

As argued in Li et al. (2016), anti-recharacterization laws allow secured creditors to seize collateral easily in case the debtor declares bankruptcy. I show that this improved ability to access collateral mainly benefits the productive efficiency of financially constrained firms: productivity of plants belonging to financially constrained firms increases, whereas there is no significant change for plants belonging to financially unconstrained firms. This finding is in line with previous research arguing that a relaxation of financial constraints induces firms to increase their productivity by adopting productivity-enhancing projects (Krishnan et al. 2014; Midrigan and Xu, 2014).

In the second part of my empirical analysis, I analyze two compositional aspects of in- 
vestment argued to be related to financial constraints and having the potential to affect productivity. First, I show that treated plants invest in capital of younger vintage and newer technology by increasing their new machinery and computer investments. Second, I document that new machinery expenditures per labor increase, which means that treated plants move towards a more mechanized and capital-intensive production. Finally, I document that these investments primarily benefit initially unproductive plants, which experience the highest increase in productivity following the enactment of laws. This finding suggests that firms now can take up productive projects for their plants they could not previously invest in, due to borrowing constraints.

My results are consistent with the view that stronger creditor rights during bankruptcy can help firms have more access to credit and to productivity-enhancing projects. My findings have crucial policy implications, especially in a time period where advanced economies suffer from dismal productivity growth. 


\section{References}

Acharya, V., Amihud, Y., Litov, L., 2011. Creditor Rights and Corporate Risk-Taking. Journal of Financial Economics 102, 150-166.

Acharya, V. V., Subramanian, K. V., 2009. Bankruptcy Codes and Innovation. Review of Financial Studies 22, 4949-4988.

Aghion, P., Bolton, P., 1992. An Incomplete Contracts Approach to Financial Contracting. Review of Economic Studies 59, 473-94.

Agrawal, A., Tambe, P., 2016. Private Equity and Workers Career Paths: The Role of Technological Change. The Review of Financial Studies 29, 2455.

Bai, J. J., 2016. Organizational Form, Strategic Restructuring, and Firm Efficiency: Plant-Level Evidence from Competitive Shocks. Working Paper .

Bertrand, M., Mullainathan, S., 2003. Enjoying the Quiet Life? Corporate Governance and Managerial Preferences. Journal of Political Economy 111, 1043-1075.

Black, S., Lynch, L., 2001. How To Compete: The Impact Of Workplace Practices And Information Technology On Productivity. The Review of Economics and Statistics 83, 434-445.

Brav, A., Jiang, W., Kim, H., 2015. The Real Effects of Hedge Fund Activism: Productivity, Asset Allocation, and Labor Outcomes. Review of Financial Studies 28, 2723-2769.

Butler, A. W., Cornaggia, J., 2011. Does Access to External Finance Improve Productivity? Evidence from a Natural Experiment. Journal of Financial Economics 99, 184-203.

Campello, M., Larrain, M., 2016. Enlarging the Contracting Space: Collateral Menus, Access to Credit, and Economic Activity. Review of Financial Studies 29, 349-383.

Cerqueiro, G., Ongena, S., Roszbach, K., 2016. Collateral Damage? The Sequel. On Liquidation Value, Credit Supply, and Firm Performance. Working Paper . 
Chaney, T., Sraer, D., Thesmar, D., 2012. The Collateral Channel: How Real Estate Shocks Affect Corporate Investment. American Economic Review 102, 2381-2409.

Eisfeldt, A. L., Rampini, A. A., 2007. New or Used? Investment with Credit Constraints. Journal of Monetary Economics 54, 2656-2681.

Feng, M., Gramlich, J. D., Gupta, S., 2009. Special Purpose Vehicles: Empirical Evidence on Determinants and Earnings Management. The Accounting Review 84, 1833-1876.

Foster, L., Grim, C., Haltiwanger, J., 2014. Reallocation in the Great Recession: Cleansing or Not? NBER Working Papers 20427, National Bureau of Economic Research, Inc.

Gan, J., 2007. Collateral, Debt Capacity, and Corporate Investment: Evidence from a Natural Experiment. Journal of Financial Economics 85, 709-734.

Garmaise, M. J., 2008. Production in Entrepreneurial Firms: The Effects of Financial Constraints on Labor and Capital. The Review of Financial Studies 21, 543.

Gatti, R., Love, I., 2008. Does Access to Credit Improve Productivity? Evidence from Bulgaria. Economics of Transition 16, 445-465.

Giroud, X., 2013. Proximity and Investment: Evidence from Plant-Level Data. The Quarterly Journal of Economics 128, 861-915.

Giroud, X., Mueller, H. M., 2015. Capital and Labor Reallocation within Firms. Journal of Finance 70, 1767-1804.

Greenman, N., Mairesse, J., 1996. Computers and Productivity in France: Some Evidence. Monash Econometrics and Business Statistics Working Papers 15/96, Monash University, Department of Econometrics and Business Statistics.

Hadlock, C. J., Pierce, J. R., 2010. New Evidence on Measuring Financial Constraints: Moving Beyond the KZ Index. Review of Financial Studies 23, 1909-1940. 
Hart, O., Drago, R. L. P., de Silanes, F. L., Moore, J., 1997. A New Bankruptcy Procedure that Uses Multiple Auctions. European Economic Review 41, 461 - 473.

Hart, O., Moore, J., 1994. A Theory of Debt Based on the Inalienability of Human Capital. The Quarterly Journal of Economics 109, 841.

Hicks, J. R., 1969. A Theory of Economic History. No. 9780198811633 in OUP Catalogue, Oxford University Press.

Janger, E. J., 2003. The Death of Secured Lending. Cardozo Law Review 25, 1759.

Kelley, M. R., 1994. Productivity and Information Technology: The Elusive Connection. Manage. Sci. 40, 1406-1425.

Kettering, K. C., 2008. True Sales of Receivables: A Purpose Analysis. American Bankruptcy Institute Law Review 16, 511.

Kettering, K. C., 2011. Harmonizing Choice of Law in Article 9 with Emerging International Norms. Gonzaga Law Review, 46:2.

King, R. G., Levine, R., 1993. Finance and Growth: Schumpeter Might Be Right. The Quarterly Journal of Economics 108, 717-737.

Korgaonkar, S., Nini, G., 2010. Special Purpose Vehicles in Nonfinancial Corporate Finance. Working Paper.

Krishnan, K., Nandy, D. K., Puri, M., 2014. Does Financing Spur Small Business Productivity? Evidence from a Natural Experiment. Review of Financial Studies .

La Porta, R., Lopez-De-Silanes, F., Shleifer, A., Vishny, R. W., 1997. Legal Determinants of External Finance. The Journal of Finance 52, 1131-1150.

Levine, O., Warusawitharana, M., 2016. Finance and Productivity Growth: Firm-Level Evidence. Working Paper . 
Li, S., Whited, T. M., Wu, Y., 2016. Collateral, Taxes, and Leverage. The Review of Financial Studies 29, 1453.

Mann, W., 2015. Creditor Rights and Innovation: Evidence from Patent Collateral. Unpublished Working Paper, University of California, Los Angeles. .

Midrigan, V., Xu, D. Y., 2014. Finance and Misallocation: Evidence from Plant-Level data. The American Economic Review 104, 422-458.

Peek, J., Rosengren, E. S., 2000. Collateral Damage: Effects of the Japanese Bank Crisis on Real Activity in the United States. American Economic Review 90, 30-45.

Ponticelli, J., Alencar, S. L., 2016. Court Enforcement, Bank Loans and Firm Investment: Evidence from a Bankruptcy Reform in Brazil. Quarterly Journal of Economics 131, 1365-1413.

Rajan, R. G., Zingales, L., 1998. Financial Dependence and Growth. American Economic Review $88,559-86$.

Schoar, A., 2002. Effects of Corporate Diversification on Productivity. The Journal of Finance 57, 2379-2403.

Seifert, B., Gonenc, H., 2012. Creditor Rights and R\&D Expenditures. Corporate Governance: An International Review 20, 3-20.

Silva, R., 2013. Internal Labor Markets and Investment in Conglomerates. Working Paper, U.S. Census Bureau, Center for Economic Studies.

Syverson, C., 2011. What Determines Productivity? Journal of Economic Literature 49, 326-65.

Vig, V., 2013. Access to Collateral and Corporate Debt Structure: Evidence from a Natural Experiment. The Journal of Finance 68, 881-928.

Whited, T. M., Wu, G., 2006. Financial Constraints Risk. Review of Financial Studies 19, 531-559. 


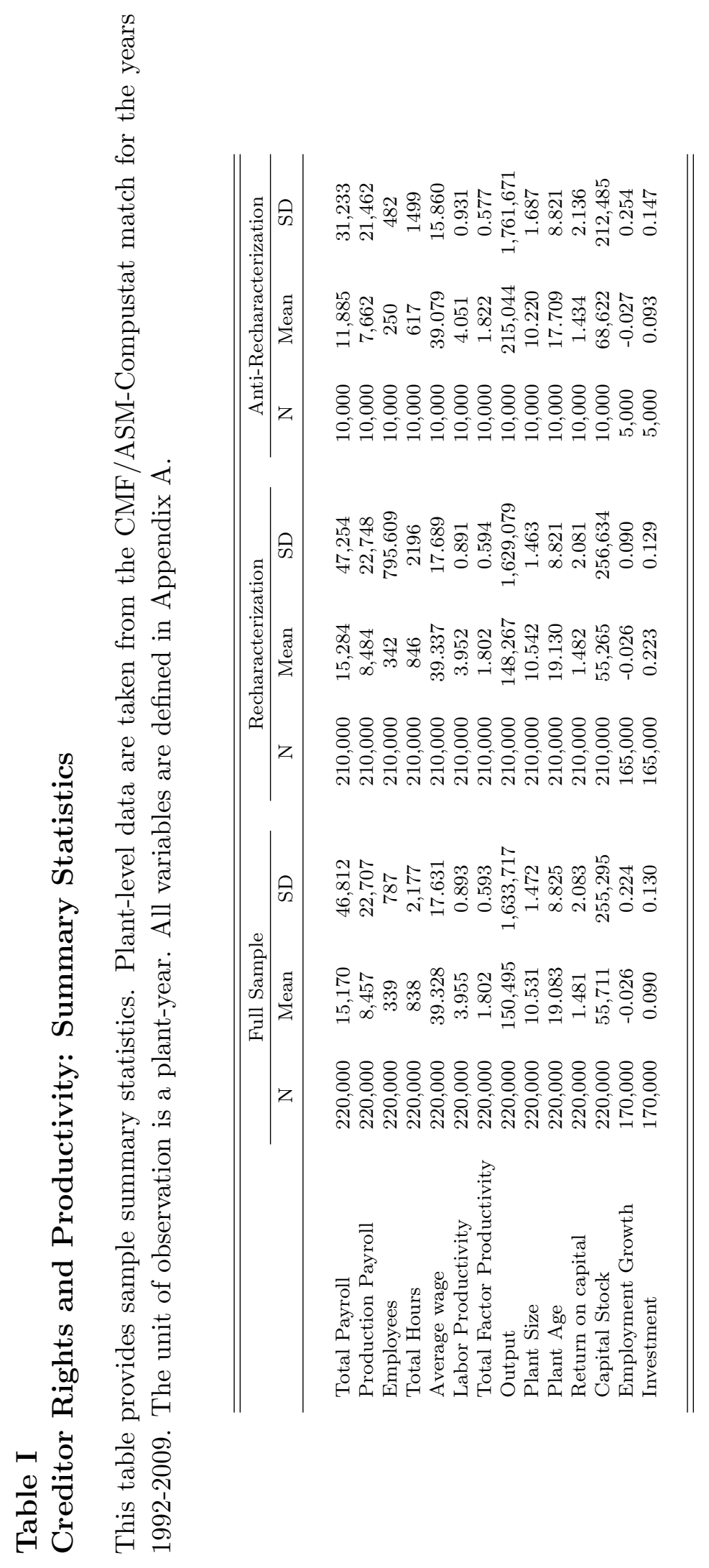




\section{Table II}

\section{Creditor Rights and Productivity: Baseline Estimates}

This table presents estimates of the plant-level impact of anti-recharacterization laws on Total Factor Productivity (TFP). The main independent variable is ARL, which is an indicator variable that equals one if firm is headquartered in a treated stated between 1997 and 2001 or incorporated in a treated state between 1997 and 2003. The unit of observation in each regression is a plant-year pair. Control variables include size and age of the plant as well as number of plants owned by the firm. All variables are defined in Appendix A. Standard errors (in parentheses) are clustered at the state of location level. $* * *, * *, *$ denotes statistical significance at the 1,5 , and 10 percent level.

\begin{tabular}{lccc}
\hline \hline Dependent Variable: Total Factor Productivity (TFP) & & & \\
& {$[1]$} & {$[2]$} & {$[3]$} \\
\hline ARL & $0.032^{* * *}$ & $0.027^{* * *}$ & $0.026^{* * *}$ \\
& $(0.008)$ & $(0.010)$ & $(0.010)$ \\
\hline Control Variables & $\mathrm{Y}$ & $\mathrm{Y}$ & $\mathrm{Y}$ \\
Plant Fixed Effects & $\mathrm{Y}$ & $\mathrm{Y}$ & $\mathrm{Y}$ \\
Year Fixed Effects & $\mathrm{Y}$ & $\mathrm{Y}$ & $\mathrm{Y}$ \\
State of Incorporation Fixed Effects & $\mathrm{N}$ & $\mathrm{Y}$ & $\mathrm{Y}$ \\
State of Headquarter Fixed Effects & $\mathrm{N}$ & $\mathrm{Y}$ & $\mathrm{Y}$ \\
State of Location-Industry-Year Fixed Effects & $\mathrm{N}$ & $\mathrm{N}$ & $\mathrm{Y}$ \\
\hline Observations & 220,000 & 220,000 & 220,000 \\
$\mathrm{R}^{2}$ & 0.77 & 0.77 & 0.74 \\
\hline \hline
\end{tabular}




\section{Table III}

\section{Creditor Rights and Productivity: Labor and Capital Productivities}

This table presents estimates of the plant-level impact of anti-recharacterization laws on labor and capital productivities. The dependent variables in columns [1] to [3] and [4] to [6] are labor and capital productivities, respectively. Labor productivity is defined as natural logarithm of value-added per labor hour. Return on capital, calculated as sales minus material and energy costs and payroll divided by plant-level capital stock, is used to measure capital productivity. The unit of observation in each regression is a plant-year pair. The main independent variable is ARL, which is an indicator variable that equals one if firm is headquartered in a treated stated between 1997 and 2001 or incorporated in a treated state between 1997 and 2003. Control variables include size and age of the plant as well as number of plants owned by the firm. All variables are defined in Appendix A. Standard errors (in parentheses) are clustered at the state of location level. ${ }^{* * *},{ }^{* *},{ }^{*}$ denotes statistical significance at the 1,5 , and 10 percent level.

\begin{tabular}{|c|c|c|c|c|c|c|}
\hline \multirow[t]{2}{*}{ Dependent Variable: } & \multicolumn{3}{|c|}{ Labor Productivity } & \multicolumn{3}{|c|}{ Return on Capital } \\
\hline & {$[1]$} & {$[2]$} & {$[3]$} & {$[4]$} & {$[5]$} & {$[6]$} \\
\hline ARL & $\begin{array}{c}0.058^{* * *} \\
(0.023)\end{array}$ & $\begin{array}{c}0.057^{* *} \\
(0.026)\end{array}$ & $\begin{array}{c}0.068^{* * *} \\
(0.032)\end{array}$ & $\begin{array}{c}0.090^{* * *} \\
(0.037)\end{array}$ & $\begin{array}{c}0.082^{* *} \\
(0.037)\end{array}$ & $\begin{array}{c}0.095^{* * *} \\
(0.036)\end{array}$ \\
\hline Control Variables & $\mathrm{Y}$ & $\mathrm{Y}$ & $\mathrm{Y}$ & $\mathrm{Y}$ & $\mathrm{Y}$ & $\mathrm{Y}$ \\
\hline Plant Fixed Effects & $\mathrm{Y}$ & $\mathrm{Y}$ & $\mathrm{Y}$ & $\mathrm{Y}$ & $\mathrm{Y}$ & $\mathrm{Y}$ \\
\hline Year Fixed Effects & $\mathrm{Y}$ & $\mathrm{Y}$ & $\mathrm{Y}$ & $\mathrm{Y}$ & $\mathrm{Y}$ & $\mathrm{Y}$ \\
\hline State of Incorporation Fixed Effects & $\mathrm{N}$ & $\mathrm{Y}$ & $\mathrm{Y}$ & $\mathrm{N}$ & $\mathrm{Y}$ & $\mathrm{Y}$ \\
\hline State of Headquarter Fixed Effects & $\mathrm{N}$ & $\mathrm{Y}$ & $\mathrm{Y}$ & $\mathrm{N}$ & $\mathrm{Y}$ & $\mathrm{Y}$ \\
\hline State of Location-Industry-Year Fixed Effects & $\mathrm{N}$ & $\mathrm{N}$ & $\mathrm{Y}$ & $\mathrm{N}$ & $\mathrm{N}$ & $\mathrm{Y}$ \\
\hline Observations & 220,000 & 220,000 & 220,000 & 220,000 & 220,000 & 220,000 \\
\hline $\mathrm{R}^{2}$ & 0.77 & 0.77 & 0.77 & 0.74 & 0.74 & 0.74 \\
\hline
\end{tabular}




\section{Table IV \\ Creditor Rights and Productivity: Dynamic Estimates}

This table presents estimates of the plant-level impact of anti-recharacterization laws on total factor, labor and capital productivities. Columns [1] to [3] use total factor productivity (TFP), labor and capital productivities, respectively, as dependent variable. Labor productivity is defined as natural logarithm of value-added per labor hour. Return on capital, calculated as sales minus material and energy costs and payroll divided by plant-level capital stock, is used to measure capital productivity. The unit of observation in each regression is a plant-year pair. Before ${ }^{-1}$ is an indicator variable that equals one if the plant belongs to a firm headquartered or incorporated in a state that will pass anti-recharacterization laws in one year. Before ${ }^{0}$ is an indicator variable that equals one if the plant belongs to a firm headquartered or incorporated in a state that passes anti-recharacterization laws that year. After ${ }^{1}$ is an indicator variable that equals one if the plant belongs to a firm headquartered or incorporated in a state that passed anti-recharacterization laws one year ago. After ${ }^{2+}$ is an indicator variable that equals one if the plant belongs to a firm headquartered or incorporated in a state that passed anti-recharacterization laws two years ago or more. Control variables include size and age of the plant as well as number of plants owned by the firm. All variables are defined in Appendix A. Standard errors (in parentheses) are clustered at the state of location level. ${ }^{* *},{ }^{* *},{ }^{*}$ denotes statistical significance at the 1,5 , and 10 percent level.

\begin{tabular}{lccc}
\hline \hline Dependent Variable: & TFP & Labor Productivity & Return on Capital \\
& {$[1]$} & {$[2]$} & {$[3]$} \\
\hline Before $^{-1}$ & -0.009 & 0.017 & 0.036 \\
& $(0.012)$ & $(0.025)$ & $(0.028)$ \\
Before $^{0}$ & 0.014 & $0.060^{* * *}$ & $0.160^{* * *}$ \\
& $(0.012)$ & $(0.016)$ & $(0.043)$ \\
After $^{1}$ & $0.039^{* *}$ & $0.100^{* * *}$ & $0.318^{* *}$ \\
& $(0.019)$ & $(0.020)$ & $(0.132)$ \\
After $^{2+}$ & $0.060^{* * *}$ & $0.090^{* * *}$ & $0.160^{* *}$ \\
& $(0.015)$ & $(0.018)$ & $(0.079)$ \\
\hline Control Variables $_{\text {Plant Fixed Effects }}$ & $\mathrm{Y}$ & $\mathrm{Y}$ & $\mathrm{Y}$ \\
Year Fixed Effects & $\mathrm{Y}$ & $\mathrm{Y}$ & $\mathrm{Y}$ \\
State of Incorporation Fixed Effects & $\mathrm{Y}$ & $\mathrm{Y}$ & $\mathrm{Y}$ \\
State of Headquarter Fixed Effects & $\mathrm{Y}$ & $\mathrm{Y}$ & $\mathrm{Y}$ \\
State of Location-Industry-Year Fixed Effects & $\mathrm{Y}$ & $\mathrm{Y}$ & $\mathrm{Y}$ \\
\hline Observations & 220,000 & 220,000 & 220,000 \\
$\mathrm{R}^{2}$ & 0.77 & 0.77 & 0.74 \\
\hline \hline
\end{tabular}




\section{Table V \\ Creditor Rights and Productivity: Placebo Treatment}

This table presents estimates of the plant-level impact of placebo anti-recharacterization laws on total factor, labor and capital productivities. In this robustness exercise, I falsely assume that states bordering Texas, Louisiana, or Alabama are treated. Columns [1] to [3] use total factor productivity (TFP), labor and capital productivities, respectively, as dependent variable. Labor productivity is defined as natural logarithm of value-added per labor hour. Return on capital, calculated as sales minus material and energy costs and payroll divided by plant-level capital stock, is used to measure capital productivity. The unit of observation in each regression is a plant-year pair. The main independent variable is ARL, which is an indicator variable that equals one if firm is headquartered in a treated stated between 1997 and 2001 or incorporated in a treated state between 1997 and 2003. Control variables include size and age of the plant as well as number of plants owned by the firm. All variables are defined in Appendix A. Standard errors (in parentheses) are clustered at the state of location level. ***, **, * denotes statistical significance at the 1,5 , and 10 percent level.

\begin{tabular}{lccc}
\hline \hline Dependent Variable: & TFP & Labor Productivity & Return on Capital \\
& {$[1]$} & {$[2]$} & {$[3]$} \\
\hline ARL & 0.009 & -0.004 & -0.039 \\
& $(0.013)$ & $(0.020)$ & $(0.051)$ \\
\hline Control Variables & $\mathrm{Y}$ & $\mathrm{Y}$ & $\mathrm{Y}$ \\
Plant Fixed Effects & $\mathrm{Y}$ & $\mathrm{Y}$ & $\mathrm{Y}$ \\
Year Fixed Effects & $\mathrm{Y}$ & $\mathrm{Y}$ & $\mathrm{Y}$ \\
State of Incorporation Fixed Effects & $\mathrm{Y}$ & $\mathrm{Y}$ & $\mathrm{Y}$ \\
State of Headquarter Fixed Effects & $\mathrm{Y}$ & $\mathrm{Y}$ & $\mathrm{Y}$ \\
State of Location-Industry-Year Fixed Effects & $\mathrm{Y}$ & $\mathrm{Y}$ & 220,000 \\
\hline Observations & 220,000 & 220,000 & 0.74 \\
$\mathrm{R}^{2}$ & 0.77 & 0.77 & \\
\hline \hline
\end{tabular}




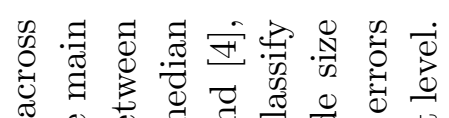
ฮ

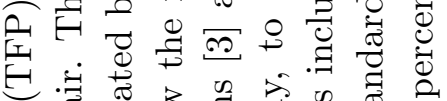

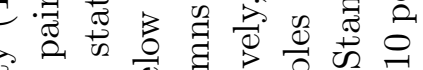

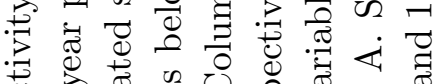

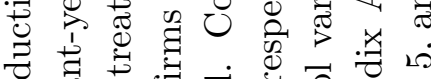

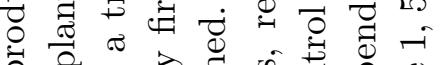

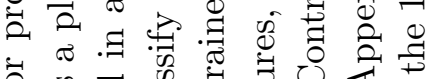

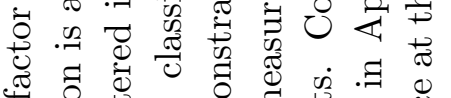

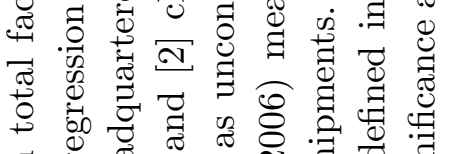
न

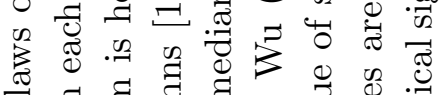

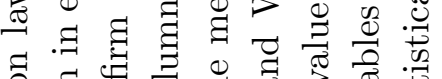

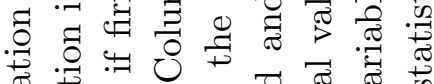

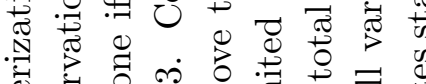

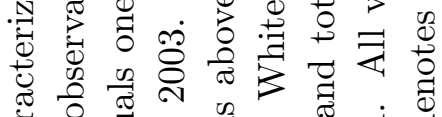

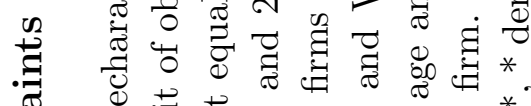

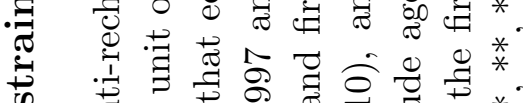

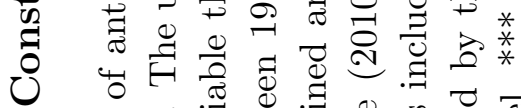
ส

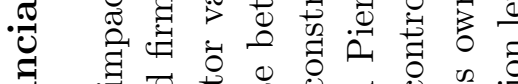

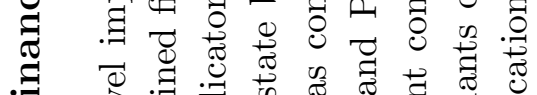

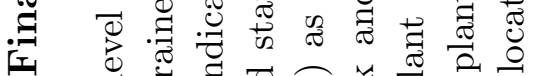
I. I

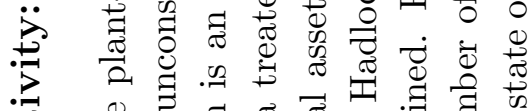

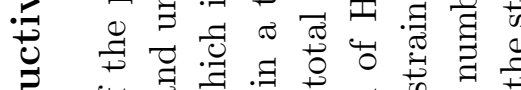
ఫ

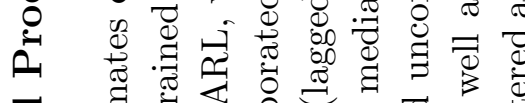

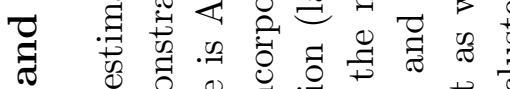
告

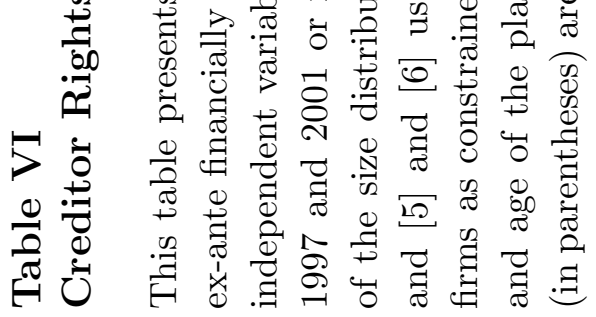

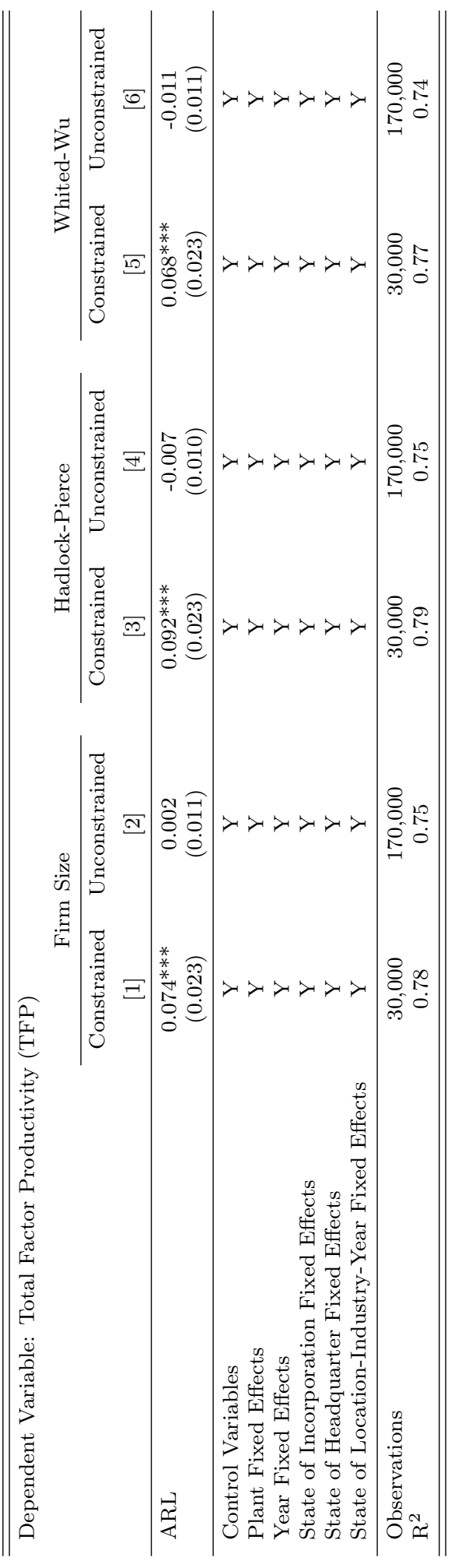




\section{Table VII \\ Creditor Rights and Productivity: Debt}

This table presents estimates of the firm-level impact of anti-recharacterization laws on long-term debt, leverage, and total debt. I define the long-term debt, leverage, and total debt as long-term debt scaled by total assets, sum of long-term and short-term debt scaled by total assets, and natural logarithm of sum of long-term and short-term debt, respectively. The main independent variable is $\mathrm{ARL}$, which is an indicator variable that equals one if firm is headquartered in a treated stated between 1997 and 2001 or incorporated in a treated state between 1997 and 2003. The unit of observation in each regression is a firm-year pair. Firm controls include natural logarithm of sales, profitability, Tobin's Q and tangibility. All variables are defined in Appendix A. Standard errors (in parentheses) are clustered at the firm level. ${ }^{* *},{ }^{* *},{ }^{*}$ denotes statistical significance at the 1,5 , and 10 percent level.

\begin{tabular}{|c|c|c|c|c|c|c|}
\hline \multirow[t]{2}{*}{ Dependent Variable: } & \multicolumn{2}{|c|}{ Long-Term Debt } & \multicolumn{2}{|c|}{ Leverage } & \multicolumn{2}{|c|}{ Total Debt } \\
\hline & {$[1]$} & {$[2]$} & {$[3]$} & {$[4]$} & {$[5]$} & {$[6]$} \\
\hline ARL & $\begin{array}{c}0.019^{* * *} \\
(0.006)\end{array}$ & $\begin{array}{c}0.018^{* * *} \\
(0.006)\end{array}$ & $\begin{array}{c}0.017^{* * *} \\
(0.006)\end{array}$ & $\begin{array}{c}0.013^{* *} \\
(0.060)\end{array}$ & $\begin{array}{c}0.136^{* *} \\
(0.058)\end{array}$ & $\begin{array}{c}0.137^{* *} \\
(0.007)\end{array}$ \\
\hline Sales & & $\begin{array}{c}0.024^{* * *} \\
(0.002)\end{array}$ & & $\begin{array}{c}0.024^{* * *} \\
(0.002)\end{array}$ & & $\begin{array}{c}0.024^{* * *} \\
(0.002)\end{array}$ \\
\hline Profitability & & $\begin{array}{c}-0.127^{* * *} \\
(0.017)\end{array}$ & & $\begin{array}{c}-0.127^{* * *} \\
(0.017)\end{array}$ & & $\begin{array}{c}-0.127^{* * *} \\
(0.017)\end{array}$ \\
\hline Tobin's Q & & $\begin{array}{c}-0.009 * * * \\
(0.001)\end{array}$ & & $\begin{array}{c}-0.009^{* * *} \\
(0.001)\end{array}$ & & $\begin{array}{c}-0.009^{* * *} \\
(0.001)\end{array}$ \\
\hline Tangibility & & $\begin{array}{c}0.106^{* * *} \\
(0.014)\end{array}$ & & $\begin{array}{c}0.106^{* * *} \\
(0.014)\end{array}$ & & $\begin{array}{c}0.106^{* * *} \\
(0.014)\end{array}$ \\
\hline Firm FE & $\mathrm{Y}$ & $\mathrm{Y}$ & $\mathrm{Y}$ & $\mathrm{Y}$ & $\mathrm{Y}$ & $\mathrm{Y}$ \\
\hline Year FE & $\mathrm{Y}$ & $\mathrm{Y}$ & $\mathrm{Y}$ & $\mathrm{Y}$ & $\mathrm{Y}$ & $\mathrm{Y}$ \\
\hline Observations & 30,000 & 30,000 & 30,000 & 30,000 & 30,000 & 30,000 \\
\hline $\mathrm{R}^{2}$ & 0.71 & 0.68 & 0.71 & 0.68 & 0.71 & 0.68 \\
\hline
\end{tabular}




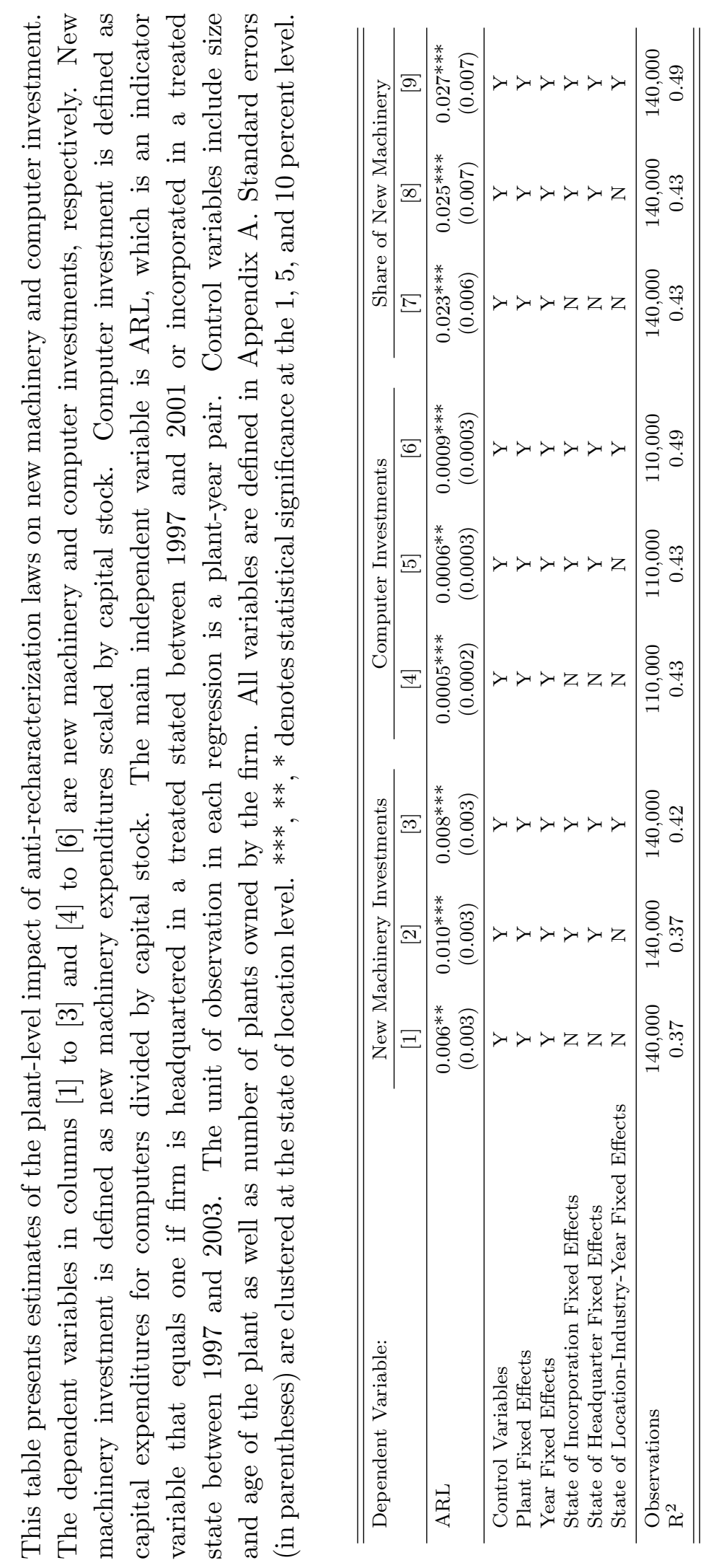




\section{Table IX}

\section{Creditor Rights and Productivity: New Machinery Expenditures Over Labor}

This table presents estimates of the plant-level impact of anti-recharacterization laws on new machinery expenditures over labor. Columns [1], [2], [3], and [4] use new machinery expenditures over total payroll, production workers' payroll, number of employees, and total hours worked, respectively, as the dependent variable. The unit of observation in each regression is a plant-year pair. The main independent variable is ARL, which is an indicator variable that equals one if firm is headquartered in a treated stated between 1997 and 2001 or incorporated in a treated state between 1997 and 2003. Control variables include size and age of the plant as well as number of plants owned by the firm. All variables are defined in Appendix A. Standard errors (in parentheses) are clustered at the state of location level. ***,**,* denotes statistical significance at the 1,5 , and 10 percent level.

\begin{tabular}{lcccc}
\hline \hline Dependent Variable: & $\begin{array}{c}\text { New Machinery } \\
\text { over }\end{array}$ & $\begin{array}{c}\text { New Machinery } \\
\text { over }\end{array}$ & $\begin{array}{c}\text { New Machinery } \\
\text { over }\end{array}$ & $\begin{array}{c}\text { New Machinery } \\
\text { over }\end{array}$ \\
& $\begin{array}{c}\text { Total Payroll } \\
\text { Eroduction Payroll }\end{array}$ & $\begin{array}{c}\text { Employees } \\
{[3]}\end{array}$ & $\begin{array}{c}\text { Total Hours } \\
{[4]}\end{array}$ \\
\hline ARL & $0.024^{* *}$ & $0.046^{* * *}$ & $1.210^{* * *}$ & $0.610^{* * *}$ \\
& $(0.010)$ & $(0.017)$ & $\mathrm{Y}$ & $(0.167)$ \\
\hline Control Variables & $\mathrm{Y}$ & $\mathrm{Y}$ & $\mathrm{Y}$ & $\mathrm{Y}$ \\
Plant Fixed Effects & $\mathrm{Y}$ & $\mathrm{Y}$ & $\mathrm{Y}$ & $\mathrm{Y}$ \\
Year Fixed Effects & $\mathrm{Y}$ & $\mathrm{Y}$ & $\mathrm{Y}$ & $\mathrm{Y}$ \\
State of Incorporation Fixed Effects & $\mathrm{Y}$ & $\mathrm{Y}$ & $\mathrm{Y}$ & $\mathrm{Y}$ \\
State of Headquarter Fixed Effects & $\mathrm{Y}$ & $\mathrm{Y}$ & $\mathrm{Y}$ & $\mathrm{Y}$ \\
State of Location-Industry-Year Fixed Effects & $\mathrm{Y}$ & $\mathrm{Y}$ & 140,000 & 140,000 \\
\hline Observations & 140,000 & 140,000 & 0.55 & 0.55 \\
$\mathrm{R}^{2}$ & 0.50 & 0.54 & & $\mathrm{Y}$ \\
\hline \hline
\end{tabular}




\section{Table X}

\section{Creditor Rights and Productivity: Productivity Change Across Plants Differing in Initial Productivity}

This table presents estimates of the impact of anti-recharacterization laws on productivity across plants differing in initial productivity one year before the treatment. Each plant is classified as productive or unproductive depending on its within-firm ranking one year before the treatment. Productive (unproductive) plants fall above (below) the median of the productivity measure of the plants belonging to the same firm one year before the treatment. The unit of observation in each regression is a plant-year pair. The main independent variable is ARL, which is an indicator variable that equals one if firm is headquartered in a treated stated between 1997 and 2001 or incorporated in a treated state between 1997 and 2003. The dependent variables in columns [1] to [2], and [3] to [4] are new machinery expenditures over total payroll and total factor productivity, respectively. Control variables include size and age of the plant as well as number of plants owned by the firm. All variables are defined in Appendix A. Standard errors (in parentheses) are clustered at the state of location level. ${ }^{* * *},{ }^{* *},{ }^{*}$ denotes statistical significance at the 1,5 , and 10 percent level.

\begin{tabular}{lccccc}
\hline \hline Dependent Variable: & \multicolumn{2}{c}{ New Machinery } & Over Total Payroll & \multicolumn{2}{c}{ Total Factor Productivity } \\
\cline { 2 - 3 } \cline { 5 - 6 } & {$[1]$} & {$[2]$} & {$[3]$} & {$[4]$} \\
\hline ARL $\times$ Unproductive & $0.031^{* *}$ & $0.041^{* *}$ & $0.061^{* * *}$ & $0.052^{* * *}$ \\
& $(0.015)$ & $(0.017)$ & $(0.016)$ & $(0.020)$ \\
ARL $\times$ Productive & 0.017 & 0.016 & 0.004 & 0.003 \\
& $(0.015)$ & $(0.015)$ & $\mathrm{Y}$ & $\mathrm{Y}$ & $\mathrm{Y}$ \\
\hline Control Variables & $\mathrm{Y}$ & $\mathrm{Y}$ & $\mathrm{Y}$ & $\mathrm{Y}$ \\
Plant Fixed Effects & $\mathrm{Y}$ & $\mathrm{Y}$ & $\mathrm{Y}$ & $\mathrm{Y}$ \\
Year Fixed Effects & $\mathrm{Y}$ & $\mathrm{Y}$ & $\mathrm{Y}$ & $\mathrm{Y}$ \\
State of Incorporation Fixed Effects & $\mathrm{Y}$ & $\mathrm{Y}$ & $\mathrm{Y}$ & $\mathrm{Y}$ \\
State of Headquarter Fixed Effects & $\mathrm{Y}$ & $\mathrm{Y}$ & $\mathrm{N}$ & $\mathrm{Y}$ \\
State of Location-Industry-Year Fixed Effects & $\mathrm{N}$ & 80,000 & 80,000 & 80,000 \\
\hline Observations & 80,000 & 0.51 & 0.85 & 0.86 \\
$\mathrm{R}^{2}$ & & & & \\
\hline \hline
\end{tabular}




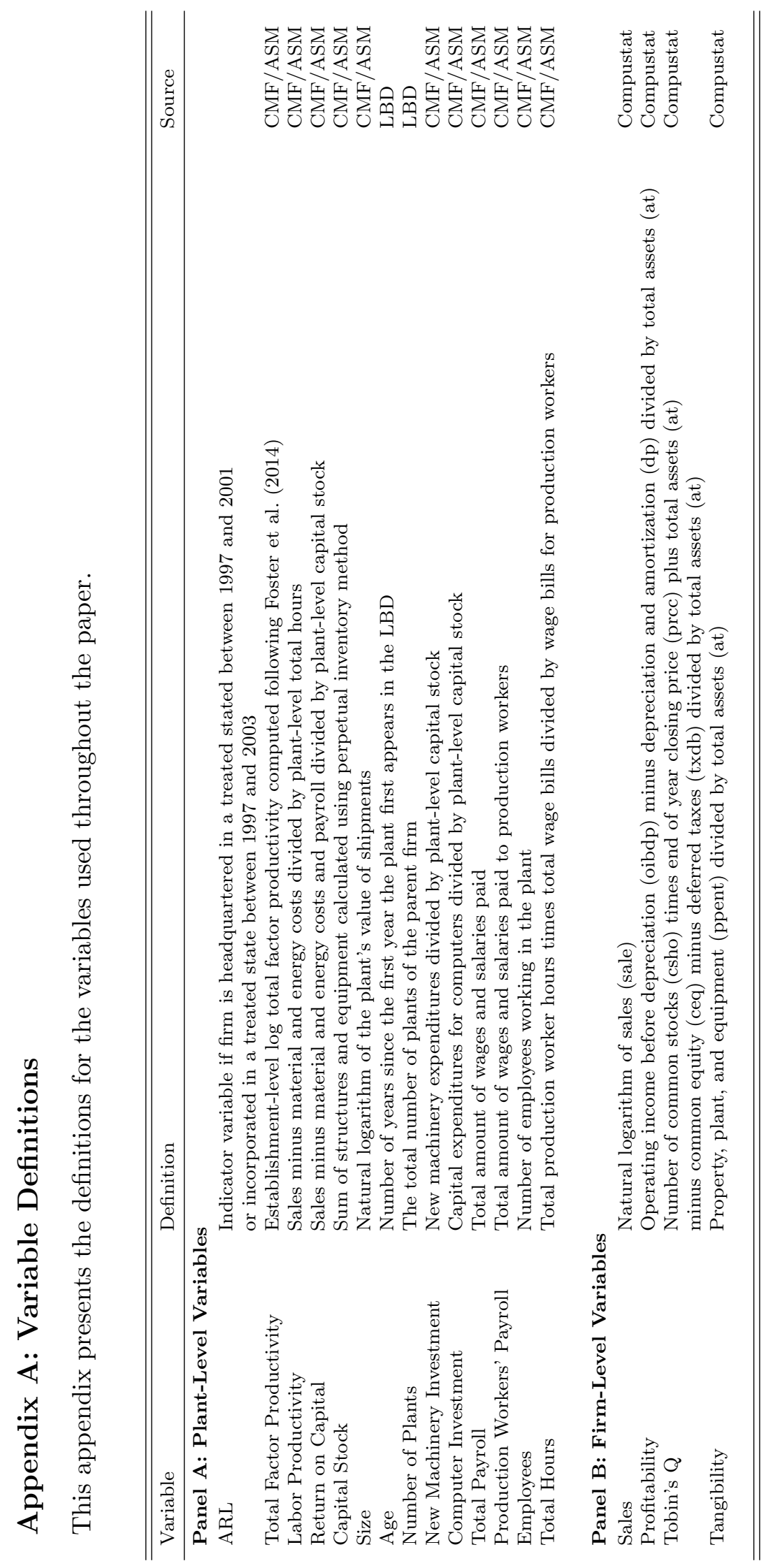




\section{Appendix B: State Laws}

\section{Texas and Louisiana}

The section below is from Texas and Louisiana Uniform Commercial Code (U.C.C.).

\section{Section 9-109. Scope}

(e) The application of this chapter to the sale of accounts, chattel paper, payment intangibles, or promissory notes is not to recharacterize that sale as a transaction to secure indebtedness but to protect purchasers of those assets by providing a notice filing system. For all purposes, in the absence of fraud or intentional misrepresentation, the parties' characterization of a transaction as a sale of such assets shall be conclusive that the transaction is a sale and is not a secured transaction and that title, legal and equitable, has passed to the party characterized as the purchaser of those assets regardless of whether the secured party has any recourse against the debtor, whether the debtor is entitled to any surplus, or any other term of the parties' agreement.

\section{$\underline{\text { Alabama }}$}

The section below are from the 2013 Code of Alabama.

\section{Section 35-10A-1}

This chapter may be referred to as the "Asset-Backed Securities Facilitation Act." It is intended by the Legislature that the term securitization transaction be construed broadly.

\section{Section 35-10A-2}

(a) Notwithstanding any other provision of law including, but not limited to, Section 7-9-506 and Section 7-9A-623, to the extent set forth in the transaction documents relating to a securitization transaction:

(1) Any property, assets, or rights purported to be transferred, in whole or in part, in the securitization transaction shall be deemed to no longer be the property, assets, or rights of the transferor;

(2) A transferor in the securitization transaction, its creditors or, in any insolvency proceeding with respect to the transferor or the transferor's property, a bankruptcy trustee, receiver, debtor, debtor in possession, or similar person, to the extent the issue is governed by $\mathrm{Al}$ abama law, shall have no rights, legal or equitable, whatsoever to reacquire, reclaim, recover, repudiate, disaffirm, redeem, or recharacterize as property of the transferor any property, assets, or rights purported to be transferred, in whole or in part, by the transferor; and

(3) In the event of a bankruptcy, receivership, or other insolvency proceeding with respect to the transferor or the transferor's property, to the extent the issue is governed by Alabama law, 
such property, assets, and rights shall not be deemed to be part of the transferor's property, assets, rights, or estate.

(b) Nothing contained in this chapter shall be deemed to require any securitization transaction to be treated as a sale for federal or state tax purposes or to preclude the treatment of any securitization transaction as debt for federal or state tax purposes or to change any applicable laws relating to the perfection and priority of security or ownership interests of persons other than the transferor, hypothetical lien creditor or, in the event of a bankruptcy, receivership, or other insolvency proceeding with respect to the transferor or its property, a bankruptcy trustee, receiver, debtor, debtor in possession, or similar person

\section{Section 35-10A-3}

Any act which becomes effective after September 12, 2001, shall not be construed to amend or repeal any provision of this chapter unless the subsequent act specifically references this chapter and states that this chapter is repealed or states the manner in which this chapter is to be amended. Without limiting the foregoing, Act 2001-481, 2001 Regular Session, does not amend or repeal any provision of this chapter. 


\section{Appendix C: Choice of Law Rules of Article 9 Uniform Commercial Code (U.C.C.)}

1972 and 2002 versions of Uniform Commercial Codes (U.C.C.) are the relevant codes for treatment states. Below is Chapter 3 of Section 9-103 of 1972 Official Text and Comments of Article 9 Secured Transactions.

\section{Section 9-103. Perfection of Security Interests in Multiple State Transactions}

(3) Accounts, general intangibles and mobile goods.

(a) This subsection applies to accounts (other than an account described in subsection (5) on minerals) and general intangibles and to goods which are mobile and which are of a type normally used in more than one jurisdiction, such as motor vehicles, trailers, rolling stock, airplanes, shipping containers, road building and construction machinery and commercial harvesting machinery and the like, if the goods are equipment or are inventory leased or held for lease by the debtor to others, and are not covered by a certificate of title described in subsection (2).

(b) The law (including the conflict of laws rules) of the jurisdiction in which the debtor is located governs the perfection and the effect of perfection or non-perfection of the security interest.

(c) If, however, the debtor is located in a jurisdiction which is not a part of the United States, and which does not provide for perfection of the security interest by filing or recording in that jurisdiction, the law of the jurisdiction in the United States in which the debtor has its major executive office in the United States governs the perfection and the effect of perfection or non-perfection of the security interest through filing. In the alternative, if the debtor is located in a jurisdiction which is not a part of the United States or Canada and the collateral is accounts or general intangibles for money due or to become due, the security interest may be perfected by notification to the account debtor. As used in the paragraph, "United States" includes its territories and possessions and the Commonwealth of Puerto Rico.

(d) A debtor shall be deemed located at this place of business if he has one, at his chief executive office if he has more than ones place of business, otherwise at this residence. If, however, the debtor is a foreign air carrier under the Federal Aviation Act of 1958, as amended, it shall be deemed located at the designated office of the agent upon whom service of process may be made on behalf of the foreign air carrier.

Below is the official comment (e) for the section above.

(e) "Chief executive office" does not the mean the place of incorporation; it means the place from which in fact the debtor manages the main part of his business 
operations. This is the place where persons dealing with the debtor would normally look for credit information, and is the appropriate place for filing.

As seen above, the 1972 version of U.C.C. defines the debtor location to be the location of the Chief Executive Office, which makes the the treatment state to be the state where the headquarter is located. The official comment explicitly states that the Chief Executive Office does not mean the place of incorporation. The 2002 version of U.C.C. changes the location of debtor to be the state of incorporation for registered organizations, as stated below.

\section{Section 9-307. Location of Debtor}

(a) "Place of business."

In this section, "place of business" means a place where a debtor conducts its affairs.

(b) Debtor's location: general rules.

Except as otherwise provided in this section, the following rules determine a debtor's location:

(1) A debtor who is an individual is located at the individual's principal residence.

(2) A debtor that is an organization and has only one place of business is located at its place of business.

(3) A debtor that is an organization and has more than one place of business is located at its chief executive office.

(c) Limitation of applicability of subsection (b).

Subsection (b) applies only if a debtor's residence, place of business, or chief executive office, as applicable, is located in a jurisdiction whose law generally requires information concerning the existence of a nonpossessory security interest to be made generally available in a filing, recording, or registration system as a condition or result of the security interest's obtaining priority over the rights of a lien creditor with respect to the collateral. If subsection (b) does not apply, the debtor is located in the District of Columbia.

(d) Continuation of location: cessation of existence, etc.

A person that ceases to exist, have a residence, or have a place of business continues to be located in the jurisdiction specified by subsections (b) and (c).

(e) Location of registered organization organized under State law.

A registered organization that is organized under the law of a State is located in that State.

\section{Section 9-102. Definitions and Index of Definitions}

(70) "Registered organization" means an organization organized solely under the law of a single State or the United States and as to which the State or the United States must maintain a public record showing the organization to have been organized. 


\section{Appendix D: Financial Constraints}

I use three measures of financial constraints:

1. Size Index: I use total assets (at). Firms above the median are coded as constrained and those below the median are coded as unconstrained.

2. Whited-Wu Index: I follow Whited and Wu (2006) in the construction of the Whited$\mathrm{Wu}$ index. It is constructed as $-0.091 \times((i b+d p) / a t)-0.062 \times \mathbb{1}(d v c+d v p>0)+0.021 \times$ $(d l t t / a t)-0.044 \times \log (a t)+0.102 \times($ average industry sales growth $)-0.035 \times$ sales growth where variables in italic represent the Compustat codes for the variables. Firms above the median are coded as constrained and those below the median are coded as unconstrained.

3. Hadlock-Pierce Index: I follow Hadlock and Pierce (2010) in the construction of HadlockPierce index. It is constructed as $0.737 \times$ Size $+0.043 \times$ Size $^{2}-0.040 \times$ Age, where Size is total assets (at) defined in 2004 dollars. Age is defined to be the number of years the firm is first listed with a non-missing stock price on Compustat. 